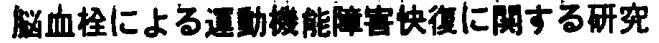

東京教育大学 本 間 茂 婎

発病経過 演者は過去 2 回脳柽塞で運動機能障害を自 ら絽唋した。第一回目は，昭和 36 年 6 月の㔖然発病で， 言語障管，少行不能に加えて，手が全く利かなくなつた が，羅病後自宅にて医師より絶対安静を命ぜられ2週間 で完全に機能を恢復した．第二回目は，本年（41年）の 5月10日の発病であつたが，それ以前より，体を前に 屈げ頭を下げると，体を起こした時に，呼吸切迫を感 し，䂹などうたつても息切机を感じながら，医師の診断 を，一日延ばしにしていたが，10日夜の会合で歩合不自 由を感したので直に帰宅安静に入つたが，血压 190〜 120. 梦行・手の上げ下げ，指の屈伸等 不可能となる. (その 数日前の 血圧睍定では160９0 余で少しわるいな と思いつつ放任:)。発病後は医師の命により，絶対安静 を守り，食事も制限し調整. 医師は，二，三日で血王降 下すると予言したが，事央二日目より 140〜80 程度に下 ク，そのまま 2 週間程安静をつづけ血压も安定し平常と なると其汇，運動意欲樴烈となり，恢復のきさしも見え 出したので，ベット上に上体を起こすことより，立つ練

\section{ちらつき优の变勤要因としての光（照明）の程頼につ いて}

\section{一目の件きと赤線外の関係一}

名古屋工業大学 鈴 木 克 三

ちらつき值（以下 F.V. と略称する）の变動要因とし ての光们の睘境を考之る場命，從米忙環境のあかるさや 色調はとりあげられてはいるが，爷動をおこさせるため に直接䄪に主役を演ずるものは環境光の中の何であるか ははつきりしていなかつた，私は本研究によつて F.V. が噮境光の如何によつて変動するのは直接的にはあかる さや色調とは殆儿ど関係なく，その主役を演ずるものは 環境光の中に含まれている郝線の有無およびその量の 多塞であることを証明し，更に F.V.の昼夜の変動む直 接的には環境光中にある赤外線の影響が主たるものであ ることを証明しようとしてその実験方法として赤外線の ない各種の環境内に括ける F.V. と赤外線を含を各種の 環境内に打汀る F.V. とを比較してみた結果, 赤外線の

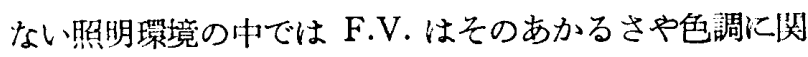
俰なく必す夜の值と同等の低い值をとるが，赤外線を含 む琞明環境の中ではその環境光中に含まれる赤外線の輻 射量の多塞に応して F.V.が变眇する現象を認め, 又そ の昼夜の変動についても自然光中では日没を境にして
習を約一週間，その都度脈搏の変化と，一日一回医師よ り血生湘定をらけ異常なきを確かめつつ, 以後歩行と手 ・肳の機能恢復運動を試みた。発病後 1 ケ月，手足の自 由殆ん之回復後，医師之相談の上，いわゆるドック入り のため慈恵医大に入院. 3 週間後，別に異常なしといわ れ退院許可. 其の間に特化, 機能快復のため専門家の一 ッーサージと共に，次の諸運動を試みた。

主な運動一仰卧脚の挙上とその屈伸，足踏，平坦地の

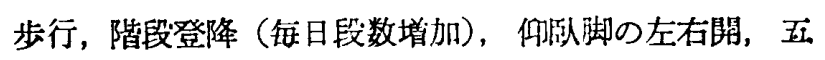
指の一斉屈伸，一本毎の屈伸，床の上の手足のタッピン ク等を, 動作の大小・楥急・強弱の变化をつけ一日に何 回となく反復, 腕の上挙・眉の回旋一日に 5 10 回宛数 回，入院中は，每日ペンにて紙上に直線書きを縦・横・ 斜と各方向に二, 三分宛行ない, 其他半径 $10 \mathrm{~cm}$ 以上 の円形書きを無数に新聞紙士汇陚を. 発病後 50 日頃上 ク，毎日原稿畫を始め小文字書きを陚む。

受けた医療手当〜1，近隣の㳊㰴の手当（注射）服楽. 2. 慈恵医大入院．3．：＂の皮下注射．4，鍼炎の針療 (残存麻湟解消).

F.V.は降下寸るが，日没後も赤外線を含を照明をつけ れば昼光下の環境と闹等の F.V.が保たれる現象を認め た.これらのことから F.V.は光的には赤外線のない光 の環境内ではいつでも低い值をとる性質をもち，赤外線 の刺韩をらけることによつてはじめて昼夜を問はず上乐 した高い值をとることがかからた，下図は自然電球の照 明環境内での赤外線の輻射最と F.V. の関係を示すもの である.

これらの尖呀から父目が物の微妙な動きをある程度以 上によりよくみるなめには光的には環摬光中に赤外線が ある程度以上存在することが必要であることもわから た。

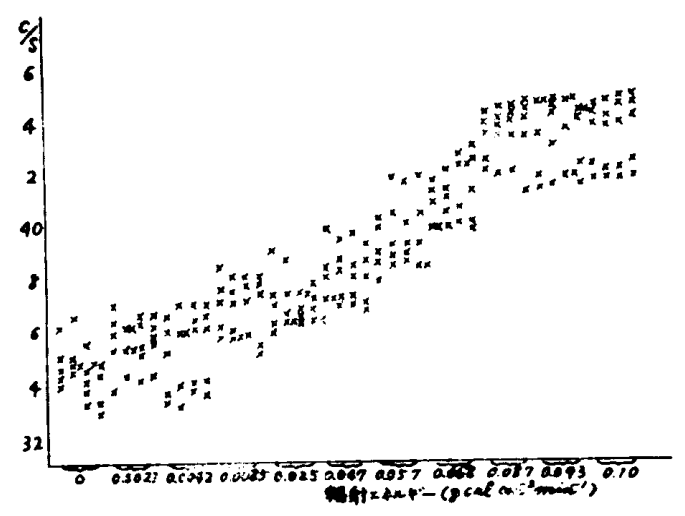

